\title{
Reformulation of a Fair Iddah Alimony Maintenance Arrangements in Indonesia's Muslim Family Law
}

\author{
Hermin Sriwulan \\ Deputy Head of Religious Court at Magelang, Indonesia \\ Student of Law Science doctoral program at Brawijaya University of Malang
}

\begin{abstract}
The obligation of husband to pay Iddah alimony in the matter of divorce (divorce filed by the husband) is normally regulated in the sources of Islamic law, Al-quran and Al-hadith. In Indonesia's family law, the husband's obligation to provide for post-divorce alimony is regulated in Article 41 letter (c) of the Marriage Law. However, the word "can" in the article contains legal ambiguity that results in not being able to provide legal certainty for the ex-wife. It provides a loophole for the ex-husband who refuses to pay iddah alimony to the ex-wife. If the husband does not pay the alimony of iddah, the ex-wife must apply for an execution which sometimes costs much more than the nominal alimony of iddah to be received. In addition, the arrangement of alimony of iddah contains legal inconsistencies, namely there is no rule when alimony of iddah is paid after the matter is decided, immediately before the trial of the pledge of divorce, or shortly after the pledge of divorce, then many husbands avoid this obligation. In the end, the judge's decision only gives justice on paper. Reformulation of fair iddah alimony maintenance arrangements in Muslim families in Indonesia is a necessity.
\end{abstract}

Keywords: payment time, alimony of iddah, fair, Muslim family law in Indonesia

DOI: $10.7176 / \mathrm{JLPG} / 104-11$

Publication date: December $31^{\text {st }} 2020$

\section{Introduction}

One of the legal obligations of a husband if he divorces his wife is to pay Iddah alimony ${ }^{1}$. If the husband does not pay, then the wife can sue him. If the judge grants him, then the judge's decision must be obeyed. ${ }^{2}$ The husband's obligation to pay alimony of iddah to his post-divorce wife is not explicitly regulated in the Marriage Law, but it is regulated in the Presidential Instructions of the Republic of Indonesia Number 1 of 1991 on the Compilation of Islamic Law (here in after referred to as KHI). However, KHI is the Presidential Instructions of the Republic of Indonesia Number 1 of 1991 which is an executive legal product and it is not binding ${ }^{3}$. Only KHI is used as a guide for Religious Court judges to fill legal vacancies.

Law No. 1 of 1974 on Marriage (here in after referred to as the Marriage Law) Article 41 letter (c) states: "The court may require the ex-husband to provide living expenses and / or determine an obligation for the exwife". The article does not specifically regulate the obligation to pay alimony of iddah for a husband who divorces his wife.

The word "can" in the article contains legal ambiguity. The word "can" also provides an opportunity for the husband to pay alimony of iddah or not to the divorced wife. The word "can" in the article contains legal ambiguity, so it cannot provide legal certainty for the wife.

Suppose the judge has firmly ruled by punishing the ex-husband to pay alimony to his ex-wife, but the ambiguity of the law in Article 41 letter (c) of the Marriage Law provides a loophole for the husband not to fulfill his obligations. In the end, the judge's decision only gave justice on paper. This can be judged not humanist ${ }^{4}$ or not glorifying the wife. It is the wife who has been living together and with her husband for a long time, but does not earn a living after divorcing her husband.

On the other hand, there are also legal inconsistencies in the payment of alimony. There is no law that strictly regulates when the alimony of iddah should be paid by the husband to his wife. In the case of divorce, for example, if the court decides that the alimony of iddah must be paid immediately before the pledge of divorce, then it is not appropriate because it leads to premature execution. Similarly, if the court orders the husband to pay alimony of iddah to his wife immediately after the pledge of divorce, then it opens the opportunity for the husband who refuses to pay to avoid the obligation.

\footnotetext{
${ }^{1}$ Iddah means the waiting period for a divorced wife, either divorced or divorced, has to wait to confirm whether the uterus is filled or empty from the womb in Slamet Abidin, et al., Fiqih Munakat II, Bandung: CV. Faithful Library. 1999, p. 121.

${ }^{2}$ Ahmad Tirmidzi, et al, Ringkasan Fikih Sunnah Sayyid Sabiq, Jakarta: Pustaka Al-Kautsar. 2013, p.471.

${ }^{3}$ Law Number 10 of 2004 concerning the Formation of Legislative Regulations Article 7 which is amended by law Number 10 of 2004 which regulates that the order of laws in force in Indonesia is 1. UUD 1945; 2. MPR Decree; 3.UU / Perppu; 4. Government Regulations; 5. Presidential Regulation; 6. Provincial Regulations; and 7. District / City Regional Regulations.

${ }^{4}$ Humanism is a school of philosophy which states that its main purpose is for the safety and perfection of humans. He views man as a noble being and the principles he recommends are based on the fulfillment of the basic needs that shape the human species in Ali Syariati, Humanisme, Antara Islam dan Mazhab Barat, Pustaka Hidayah, Bandung, 1996, p. 39.
} 
As a result, the judge's decision on the time the alimony of iddah is paid tends to vary. Some follow Jurisprudence and some do not include a dictation about when a husband should give alimony to his wife. This implies the inability to provide certainty and legal protection for the wife to obtain the right of alimony iddah in accordance with the amar of the judge's decision.

Thus the regulation of iddah alimony for the wife must be re-arranged and regulated in law in order to provide legal protection over the rights of the wife after divorce. So the wife who divorces her husband automatically obtains her right to iddah alimony without having to sue her husband first, or if the husband refuses to pay iddah alimony when the matter is in force (incraht), the wife does not have to bother paying the execution of application fee for her right in the form of iddah alimony because it is guaranteed by law in accordance with the concept of the Marriage Law that one of the obligations of the husband is to provide alimony to his wife.

This problem is the background of the author to discuss "Reformulation of a Fair Iddah Alimony Maintenance Arrangement in Indonesia's Muslim Family Law". The discussion focused on the reform of the maintenance of iddah alimony on divorce which is a competency of the Religious Court.

\section{Discussion}

\subsection{The Meaning of Iddah and Iddah Alimony}

Iddah is the waiting time of a woman who is divorced by her husband. At that time she was not allowed to accept a proposal or marry another man. This Iddah was also known in pre-Islamic times. After the advent of Islam, Iddah is still recognized as one of the teachings of sharia because it contains many benefits. ${ }^{1}$

Scholars agree on the obligation of iddah. This is normally regulated in the Qur'an surat al-Baqarah verse $228 .^{2}$ The period of iddah is the waiting period for a wife who has divorced her husband, either divorced due to death, or a court decision. The Iddah period only applies to wives who have had a husband-wife relationship. Another case is if the wife has not had a husband-wife relationship (qabla dukhul) then she does not have Iddah time. ${ }^{3}$

One of the purposes of iddah is for ta'abud, meaning merely to fulfill the will of Allah even though in ratio it is no longer needed. For example, a woman whose husband has died and has not been molded by her husband is still obliged to undergo Iddah, although it can be ensured that her ex-husband did not leave seedlings in his wife's womb. ${ }^{4}$

As for iddah according to the Law of Marriage is for a woman who has husband divorced her, the time of waiting (during iddah) applies to her, unless a wife is divorced by her previous husband (qabla al-dukhul), whether due to death, divorce, or by decision court. Article 11 paragraph (1) For a woman whose marriage is terminated, there is a waiting period; (2) The waiting period contained in paragraph (1) further shall be regulated in Government Regulation Number 9 of 1975 on the implementation of Law Number 1 of 1974 on Marriage. The explanation of the waiting period is set out in CHAPTER VII Article 39 with the following formula:

2.1.1 The waiting time for a widow as referred to in Article 11 paragraph (2) of the Law is determined as follows:

2.1.1.1 If the marriage is terminated by death, the waiting time is set at 130 (one hundred and thirty) days;

2.1.1.2 If the marriage is terminated due to divorce, the waiting period for the remaining month is set 3 (three) times holy with at least 90 (ninety) days and for those who do not come, the month is set 90 (ninety) days;

2.1.1.3 If the marriage is broken while the widow is pregnant, the waiting period is set until giving birth.

2.1.2 There is no waiting period for a widow who has divorced because the divorce is between the widow and her ex-husband has never had sex.

2.1.3 For marriages that break up due to divorce, the waiting period is calculated since the fall of the Court which has permanent legal force, while for marriages that are broken due to death, the waiting period is calculated since the death of the husband.

In the period of Iddah the wife has rights and obligations including: ${ }^{5}$ Women who are obedient in the Iddah (talak raj'iyah) are entitled to receive from their ex-husband residence (house), clothes, and all expenses, except the disobedient wife, not entitled to receive anything- what. The basis of the law is the hadith of the Prophet which means: "From Fatimah bint Qais:" The Prophet (peace and blessings of Allaah be upon him) said, to her: a woman who is entitled to take alimony and a house from her ex-husband when her ex-husband has the right to refer to her."(Reported by Ahmad and Nasai). ${ }^{6}$

\footnotetext{
${ }^{1}$ Syaikh Kamil Muhammad Uwaidah, Fiqih Wanita, penerjemah M. Abdul Ghoffar, Jakarta: Pustaka Kautsar, 1998 , p. 448

${ }^{2}$ Meaning: "The women who are bullied, refrain (wait) three times quru "'. (Surah al-Baqarah: 228).

${ }^{3}$ Zainuddin Ali, Hukum Perdata Islam di Indonesia, (Jakarta: Sinar Grafika, 2006), p. 87.

${ }^{4}$ Amir Syarifuddin, Hukum Perkawinan Islam di Indonesia, Jakarta: Kencana Prenada Media, 2006, p. 305.

${ }^{5}$ Sulaiman Rasjid, Fiqih Islam, Bandung: Penerbit Sinar Baru, 1992, h. 386

${ }^{6}$ Syaikh Faishol bin Abdul Aziz Ali Mubarok, Nailul Authar, Penerjemah. A. Qadir Hasan dkk, Surabaya: PT. Bina Ilmu, 1984, p. 2436.
} 
Alimony is all the needs and wants of the wife that apply according to the situation and place, such as food, clothing, home and more. ${ }^{1}$ The amount of alimony given is in accordance with adequate needs and in accordance with the husband's ability. The obligation of the husband to provide for his wife is not only at the time of marriage, but also at the time of the husband divorcing his wife / alimony iddah as Allah says in QS. At-Thalaq verse $1 .^{2}$

\subsection{Types of Iddah}

2.2.1 Iddah Talaq means Iddah that occurs due to divorce. Women who are in the iddah talak among others: ${ }^{3}$

2.2.1.1 Women who have been mixed and have not stopped during menstruation.

The majority of scholars are of the opinion that the period of iddah that must be lived is three times the period of menstruation (Quran surat al-Baqarah verse 228 ').

2.2.1.2 Iddah for a wife who is divorced and has not had a period of menstruation (monopause) for three months (Qurán Surat Ath-Thalaq verse: 4). ${ }^{4}$

\subsubsection{Iddah while Pregnant (Iddah Hamil)}

Iddah hamil is Iddah for women who are divorced during pregnancy. Their iddah is to give birth to a child (Qurán surat at-Thalaq verse 4). ${ }^{5}$

2.2.3 Iddah of Death Husband (Iddah Wafat)

Iddah wafat is an Iddah that occurs when a woman is left dead by her husband. The Iddah is four months ten days (Qurán surat al-Baqarah verse 234). ${ }^{6}$

2.2.4 Iddah of a woman whose husband is lost

If a woman loses her husband, and it is not known where her husband is, whether he is dead or still alive, then she must wait him four years. After that she is in Iddah condition for four months and ten days. ${ }^{7}$

\subsection{Reformulation of a Fair Iddah Maintenance Arrangement}

\subsubsection{Through the Rights of Ex Officio the Judge}

In divorce cases, it is often found that the amar decision that grants it by giving permission to the applicant (husband) to pronounce the pledge of talaq and it is accompanied by punishing the applicant to pay the petitioner property in the form of $m u t^{\prime} a h$, alimony of Iddah and other alimony related to the obligation of the husband to the wife he divorced. In general, amar in some divorce cases in the Religious Court only mentions a few elements, including the elements of the subject paying, the object paid, the amount and form of property to be paid and the type of payment, but the amar does not contain the payment deadline. Whereas on the other hand which is closely related to it, the period of pronouncing the pledge of divorce is limited by a maximum time of 6 (six) months after the date of the divorce pledge. ${ }^{8}$

On the day of the hearing of the pronouncement of divorce that has been set such as the applicant (husband) and the petitioner (wife) present at the trial, but the applicant is not ready to pay Iddah alimony or the right of the petitioner charged to him to be handed over to the applicant, it is not a few found the jury tried to suggest Applicant to postpone the pronunciation of the pledge of divorce until it is ready with the burden given to the Applicant. ${ }^{9}$

From a glimpse of the meaning of Iddah alimony above, it can be understood that alimony of Iddah is the alimony given by the ex-husband to the ex-wife and who still has the right to refer, so the alimony of Iddah is very useful for the survival of the wife after the divorce. Therefore the main principle of Iddah alimony is the time of its use (used during the period of Iddah) not the time of payment. It may be that both parties have a strong desire to divorce regardless of where the beginning of the cause of the dispute and the quarrel or the cause. However, the problem is that the man (husband) is willing to pay the maintenance of iddah, it turns out that after pledging to divorce, there is no one knows where he was. In addition, legal measures through execution are very burdensome for women (ex-wives) because the cost of execution in court is half, almost the same, or even greater than the

\footnotetext{
${ }^{1}$ Sulaiman Rasjid, Fiqh Islam, Bandung: Penerbit Sinar Baru Algensindo Bandung Anggota IKAPI, 2012, p. 421.

${ }^{2}$ Meaning: "O Prophet, if you divorce your wives, then you should divorce them when they can (face) their iddah (which is reasonable) and count the iddah time and fear Allah your Lord. Thou shalt not bring them out of their houses, nor shall they (be permitted) go out unless they are engaged in clear abominable deeds. These are the laws of Allah, So Verily He has done wrong against himself. you do not know perhaps Allah Will do after that something new."

${ }^{3}$ Slamet Abidin and Aminuddin, Fiqih Munkahat, Bandung: CV Pustaka Setia, 1999, p. 122

${ }^{4}$ Meaning: "And women who are no longer menstruating (menopause) among your women if you are in doubt (about their iddah period), then their iddah period is three months; and so (also) women who do not menstruate ".

${ }^{5}$ Meaning: "And women who are pregnant, their iddah time is until they give birth to their womb and whoever is obedient to Allah, Allah will make it easy for him in his affairs".

6 "Those who died among you by leaving their wives (let the fig wife) postpone themselves (beriddah) four months and ten days".

${ }^{7}$ Hadith from Umar narrated by Imam Malik which means: "From Umar r.a. said, "For a woman who has lost her husband and she does not know where he is, in fact the woman is obliged to wait four years, then let her give four months and ten days, then she can get married." (HR. Malik). Imam Malik Ibn Anas, Al-Muwatta ', Translator. Dwi Surya Atmaja, Jakarta: PT. Raja Grafindo Persada, 1999 , p. 313.

${ }^{8}$ See Article 131 No. (4) Kompilasi Hukum Islam.

${ }^{9}$ Kusnoto, Masa Pembayaran Mutah Dan Nafkah Iddan Kaitannya Dengan Hak Pengucapak Ikrar Talak (kajian Purusan Perkara Cerai Talak Yang Memuat Beban Mut'ah Dan Nafkah Iddah), badilag.net, accessed November $2^{\text {nd }} 2020$.
} 
alimony of iddah that she will receive in accordance with the dictates of the judge's decision.

A verdict is a statement of a judge as an official of the state authorized for it and pronounced in a conference that open to the public with a view to resolving a matter or dispute between the parties to the matter. ${ }^{1}$ In addition, according to Abdul Manan, ${ }^{2}$ the verdict is the final conclusion taken by the panel of judges authorized for it in resolving or settling a dispute between the parties to the matter and speaking at a public hearing.

The verdict is the crown of the judge, which can provide justice for the seeker of justice, but justice alone is not enough. Because a verdict must also contain elements of legal certainty, as well as benefits. If it turns out that the decision actually creates a new problem then the decision does not give a sense of legal certainty which provides benefits for both parties. Justice seekers (justiabelen) only hope that the implementation of the law is for human beings, so in implementing the law should not cause unrest in society. Law is implemented with the aim of achieving justice, so that with the enforcement of the law will give a sense of justice to society.

In practice, the payment of Iddah alimony and mut'ah can be in the form of a claim (reunion) from the applicant and can also be ex officio ${ }^{3}$ (judge because of his position) ${ }^{4}$ in the judge's decision is condemnatoir (punishing), because of its nature then a legal obligation that must be implemented by the applicant (husband), but seeing the reality that occurs as mentioned above then this becomes a problem in the implementation of the pledge of divorce. Unfortunately, in the Qur'an, Sunnah, the book of jurisprudence and the Compilation of Islamic Law, even the law in Indonesia has not been found the definite notion regarding the time limit for the payment of Iddah alimony. ${ }^{5}$

In the absence of a clear legal rules about the time of Iddah alimony payment by the applicant, it is actually a space for the judge to make a legal breakthrough by giving his own consideration about the payment time of mut'ah and Iddah of course with logical consideration with the content of justice, certainty law and utility.

From a philosophical aspect, the consideration payment of Iddah alimony and mut'ah made before the pledge of divorce is an ijitihad from the judge collectively, the policy is done as a step in enforcing the law and fighting for the wife's alimony which should be fulfilled by the husband. Judge's ijtihad is allowed in Islamic law, the judge is positioned as a mujtahid who must draw conclusions and establish the law. Ijtihad of a judge is forbidden when things already have its law and have been determined based on definite arguments /qath'i. So when there is a matter that does not have a legal ruling, then the judge is allowed to perform ijtihad as long as the ijtihad does not violate the existing rules and it is used to uphold justice and the welfare of the ummah.

The ijtihad performed by the judge is an attempt to fight for justice and prosperity by setting the payment of alimony before the pledge of divorce. The judge's ijtihad is also in accordance with the purpose of law, which is an ethical theory that merely puts justice first. It is based on the principle of ius lustitia est constans et perpetua ius suum cuique tribuere (give to each what person is his right). The wife's right to obtain alimony from her husband until the time of her Iddah is completed and the judge's efforts in overcoming her husband's dishonesty through the determination of alimony payment before the divorce pledge.

From a sociological aspect, that step The judge in fighting for his wife's alimony is through a persuasive approach, not immediately punished for paying the specified amount, but also looking at the applicant's ability and willingness to pay. So that there is no reason for denying the payment, while the debtor is willing to pay and agree to accept. Also he wants to accept without feeling the loss and as if to achieve the benefit of both parties to the matter. The method used by the jury is an attempt to fight for the wife's alimony, because no one feels harmed. The move is also in line with the utility theory that the sole purpose of law is to create benefits. ${ }^{6}$

From what is described above, at least the judge in deciding matters, especially divorce, should not think and judge procedurally (normative), but should have legal breakthrough efforts as a measure of legal discovery (legal rechtvinding) in filling the vacancy, thus including a framework of thinking (legal frame) and substantive justice.

\subsubsection{Through the Reformulation of the Rules in the Law}

The results of a 2010 study conducted by Stijn Van Huis of the Van Vollen Hoven Institute of the Netherlands University of Leiden in the Religious Court of Cianjur, it revealed the problem of execution or implementation of amar difficult decisions to enforce if the ex-husband or father did not want to carry out the decision amar willingly. Even though many wives have struggled to fight for the right to support themselves and their children in court. ${ }^{7}$

\footnotetext{
${ }^{1}$ Abdul Manan, Penerapan Hukum Acara Perdata di Lingkungan Peradilan Agama, (Jakarta: Penerbit Kencana, 2005$)$, p. 292.

${ }^{2}$ Abdul Manan, Penerapan Hukum Acara Perdata di Lingkungan Peradilan Agama, (Jakarta: Penerbit Kencana, 2005 ), p. 292.

${ }^{3}$ Ex officio right comes from the Latin ambtshalve (Dutch) meaning because of the position in Marjanne Termorshuizen, Dutch Legal Dictionary, (Jakarta: Djambat, 1999), p. 22. Subekti explained that ex officio rights are rights that are owned because of their position, not based on a letter of determination or appointment, nor based on an application. one of them is to break or give something that is not in the charges. The ex officio right of the judge is owned by the judge even though this right is not present in the demands of the wife in divorce in Tjitrosoedibio, Kamus Hukum, (Jakarta: Pradnya Paramita, $4^{\text {th }}$ published., 1979), p. 43

${ }^{4}$ See article 41 letter (c) of Law Number 1 of 1974 concerning Marriage.

${ }^{5}$ Kusnoto, Ibid.

${ }^{6}$ Machmudin, Dudu Duswara, Pengantar Ilmu Hukum; Sebuah Sketsa, Bandung: PT Refika Aditama, 2003, p. 26.

${ }^{7}$ Ali/Inu, "Mantan Suami Kerap Abaikan Pemenuhan Hak Nafkah Pasca Cerai," in http://www.hukumonline.com, accessed on December 12
} 
There is a decision that punishes the husband to pay Iddah alimony to the wife in the matter of divorce in the Religious Court. Then, the husband must submit to implement the decision. Unfortunately, the understanding of the payment of Iddah alimony and mut'ah is only understood as a legal obligation implemented as an implication of divorce which does not see further benefits for the ex-wife. Especially after the husband utters a pledge of divorce then leaving and his whereabouts are unknown by leaving the burden of obligation decided by the Religious Court. Sometimes during the divorce ceremony the husband is not present, so the decision is non executable.

Based on the problem, it means that the decision handed down by the judge has not given legal certainty to the ex-wife on her right to receive Iddah alimony. Thus, legal thinking is required by the Judge, both in the form of legal breakthroughs that are the result of ijtihad on the basis of welfare and as a legal reform in order to protect the rights of women who have been much harmed. In addition, there is also a need to reform the arrangement of fair Iddah alimony.

In addition to philosophical problems, the rules of Iddah alimony also contains theoretical problems. The concept of the rights and obligations of the husband and wife after divorce, one of them is to pay Iddah alimony, but the existing norms still give the husband the opportunity to avoid the obligation to pay alimony of Iddah. In order for the rights and obligations of husband and wife in alimony of Iddah to be fulfilled, it is necessary to reform the arrangement of alimony of Iddah. The purpose of reforming the maintenance of Iddah alimony is to provide justice and legal certainty.

In addition, there are also legal problems, namely the ambiguity of norms and incompleteness of norms. The ambiguity of the norm is in Article 49 paragraph (1) of the Marriage Law lies in the phrase "can", which opens the opportunity for the husband to default on the obligation to pay. There are also incomplete norms about the mechanism of payment of Iddah alimony, including when the alimony of Iddah must be paid.

The next problem is a sociological problem. The rule of law in Article 41 letter (c) of the Marriage Law stated that the alimony of Iddah cannot bring benefits to the effort to protect the rights of the wife after divorce, so the ex-wife does not get her rights after divorce because there is no clear mechanism of alimony payment. The Iddah alimony so far has not been paid in the beginning because it is considered premature execution, but paid immediately after the pledge of divorce. Finally, if the husband does not want to pay the alimony of Iddah, then the wife does not get the right that should be obtained and still have to apply for an execution that costs far more than the amount of Iddah alimony. If the wife has no cost to apply for execution, then the justice obtained by the wife is only justice on paper.

Normally, the Marriage Law does not explicitly regulate the obligation to pay alimony of Iddah. Article 41 letter (c) of the Marriage Law only regulates in general that: "The consequences of the divorce are:" The court may require the ex-husband to provide expenses living and / or determine an obligation for the ex-wife ". The word "can" in the article contains ambiguity of law, so that the judge ex officio can punish the husband to pay alimony of Iddah to the wife or not. The word "can" also provides an opportunity for the husband to pay the alimony of Iddah or not to the divorced wife.

On the other hand, the Marriage Law and even the Religious Court of Law also do not specifically regulate the obligation to pay the Iddah alimony for a husband who divorces his wife. The Marriage Law only stipulates that "as a result of the dissolution of the marriage due to divorce is: The court may oblige the ex-husband to provide the cost of living and / or determine an obligation for the ex-wife".

The presence of legal inconsistencies in the payment procedure of Iddah alimony is the next problem. There is no law that strictly regulates when the alimony of Iddah should be paid by the husband to his wife. In the case of divorce, for example, if the court decides that the alimony of Iddah must be paid shortly before the pledge of divorce, then it is considered inappropriate because it causes premature execution. Similarly, if the court orders the husband to pay alimony of Iddah to his wife immediately after the pledge of divorce, then it opens the opportunity for the husband who refuses to pay to avoid the obligation.

This is reinforced by the Circular Letter of the Supreme Court (here in after referred to as SEMA) Number 3 of 2015 which stipulates that: "In amar divorce decision, there is no need to add a sentence 'Order the Applicant to pay or pay the burden due to divorce shortly before or after the declaration of pledge divorce', due to premature execution". On the other hand there is also a jurisprudence which in its dictum commands the husband to pay alimony shortly before the pledge of divorce. Furthermore, the SEMA is dissolved with SEMA Number 1 of 2019 which stipulates that the ex-husband must pay alimony to the ex-wife in accordance with the amar decision, just before the pledge of divorce.

As a result, the judge's decision on when the alimony of Iddah is paid tends to vary. Some follow Jurisprudence and some do not include a dictation about when a husband should give alimony to his wife. This implies the inability to provide certainty and legal protection for the wife to obtain the right for Iddah alimony in accordance with the amar of the judge's decision. 
Thus the regulation of Iddah alimony for the wife must be re-arranged and regulated in law in order to provide legal protection over the rights of the wife after divorce. So the wife who divorces her husband automatically obtains her right to Iddah alimony without having to sue her husband first, or if the husband refuses to pay it at the time the matter is incraht, the wife does not have to bother paying the cost of execution application for her right in the form of alimony which has been guaranteed by law in accordance with the concept of the Marriage Law that one of the obligations of the husband is to provide for his wife.

The Marriage Law does not explicitly regulate alimony for Iddah, but it is regulated in the Presidential Instructions of the Republic of Indonesia Number 1 of 1991 on the Compilation of Islamic Law. Article 149 KHI stipulates: "as a result of the dissolution of the marriage when the marriage is dissolved due to divorce, then the ex-husband is obliged: (1). "Giving $m u t^{\prime} a h^{1}$ a decent to his ex-wife"; (2). "Giving alimony, maskan ${ }^{2}$ and kiswah $^{3}$ to the ex-wife during the Iddah". ${ }^{4}$

Article $151 \mathrm{KHI}$ also stipulates that: "ex-wife who is in the period of Iddah must take care of herself, do not accept the proposal and do not marry another man". The ex-husband must fulfill the alimony of birth which is called Iddah alimony to the wife as a right that must be obtained by the wife. The obligation to pay alimony of iddah for the husband is a logical consequence of the legal act of divorcing the wife, except the wife of nusyuz then she is not entitled to alimony of Iddah. ${ }^{6}$ Similarly, according to Article 149 letter (b) Compilation of Islamic Law states that: "Marriage that is broken due to divorce, then the ex-husband is obliged to provide alimony, maskan and kiswah during the period of Iddah that is eligible for his ex-wife except nusyuz".

KHI has indeed firmly arranged the obligation of the husband who divorces his wife to give Iddah alimony to his wife. This is a problem because KHI which has been used as a reference for material legal rules for the judges of the Religious Court, notably as the Presidential Instructions of the Republic of Indonesia Number 1 of 1991 which is an executive legal product is not binding.

Finally, Indonesia can take the example of the family law in some Muslim countries, namely in Egypt ${ }^{7}$ and Saudi Arabia ${ }^{8}$ which provides punishment in the form of al-Hajru (Restriction / Block), al-Ikrah al-Badani (Force of the Body), al-Habsu (Prisoner) / Prison for the husband who does not want to pay Iddah alimony. ${ }^{9}$ The concept of the unpaid Iddah alimony is a debt. So the husband will be released from custody if he has paid Iddah alimony to his wife or there is another party who guarantees to pay the Iddah alimony. But with spirit restorative justice should not be necessary to imprison the husband who does not pay Iddah maintenance. The breakthrough that needs to be done is also the need for cooperation with related agencies namely the Office of Religious Affairs and the Office of Civil and Population Registration. When the husband does not pay Iddah maintenance, and the statistical data is integrated between the three agencies that, then the ex-husband will not be able to marry again because it is still recorded to have Iddah alimony debt, unless he has already paid the debt. Similarly, if he is married to another woman, the child from his marriage cannot get a birth certificate from the civil registration office if he has not paid the Iddah alimony debt to his ex-wife.

The next reform of the maintenance of Iddah alimony is about the time, which is to be paid for a moment before the pledge of divorce becomes important. The need for a judicial review of Article 41 letter (c) of the

\footnotetext{
${ }^{1}$ Mut'ah is a gift from a husband to his wife when he divorces her.

${ }^{2}$ Maskan means a proper place to live as described in the QS. Ath-Thalaq verse 6.

${ }^{3}$ Qiswah or kiswah is proper clothing as described in QS. Al-Baqarah verse 233.

${ }^{4}$ Nuansa Aulia Editorial Team, Op.Cit, p. 149

${ }^{5}$ Nusyuz is linguistically derived from the Arabic word: nazyaya-yansyuzu nasyazan wa nusyuzan, which means to raise, stand out, disobey, oppose, or act violently in Ahmad Warson Munawwir, Al-Munawwir: Arabic-Indonesian Dictionary, (Yogyakarta: Progressive Pustaka, 1997 ), h. 1418-1419. Disobedience to husband or wife or change in attitude of husband or wife. In usage, the meaning of the word an-nusyuuz develops into al-'ishyaan which means disobedience or disobedience. According to terminology, nusyuz has several meanings including: According to the Hanafiyah fuqaha as stated by Saleh Ganim, it defines it by the displeasure that occurs between husband and wife. The Maliki school of thought scholars argue that nusyuz is the persecution of husband and wife. Meanwhile, according to the scholars Syafi'iyah nusyuz is a dispute between husband and wife, meanwhile the Hambaliyah ulama defines it with displeasure on the part of the wife or husband accompanied by disharmonious relationships.

${ }^{6}$ There are 3 (three) rights of a divorced wife from her husband, namely:

a). Talak raj'i, the rights received by a former wife as applicable when married before the divorce, both clothing and food and a place of residence.

b). Talak ba'in, both ba'in sughra or ba'in kubra and she is pregnant, is entitled to a living and a place to live based on QS. at-Thalaq verse 6. If the wife is not pregnant does not get a living, maskan and kiswah (Article 149 letter (b) KHI.

c). If a wife is divorced while pregnant, the scholars agree that the wife has the right to support and a place to live, but if she is not pregnant, the scholars have disagreements, namely: Imam Malik. Imam Syafi'iy said "the right to a place to live", while some other scholars such as Imam Ahmad were of the opinion that if the wife is not pregnant then she is not entitled to a living and a place to live, because there are rights in the form of inheritance.

${ }^{7}$ Qanun Tandzim Ba'dh Auda' Wa Ijra'aat al-Taqaadiy Fii Masaail al-Ahwal alSyakhshiyyah, published in website (www.jurispedia.org/eg) accessed on November $3^{\text {rd }} 2020$.

${ }^{8}$ Based on the hadith From Amr bin al-Syarid, from his father, from Rasulullah SAW said: Suspension of a person who is able (to pay off obligations), can be forced and put in prison. Ibn Mubarak interpreted (syarah) the hadith that the phrase "Irdahu" means being forced to pay off his obligations, and the phrase "uqubatuhu" means being put into custody in Imam al-Hakim, al-Mustadrak 'ala al-Shahihain, Kitab alAhkam, Hadith No. 7165, Cet. II, Cairo.

${ }^{9}$ Ester van Eijk, Sharia incorporated, Sharia and National Law in Saudi Arabia, Leiden: Leiden University, p. 163.
} 
Marriage Law by deleting the word "can" and adding strict sanctions for the husband who does not want to pay Iddah alimony so as to give a detrimental effect to the husband because non-arrears of arbitrary alimony is a debt.

\section{Conclusion}

From the above discussion, it can be concluded that the reform of the maintenance of Iddah alimony is a must. This aims to provide justice and legal certainty for the ex-wife to obtain her right to Iddah alimony. Reformulation can be done through:

3.1 Rights ex officio judge ofto include in the dictum of the decision that the applicant was sentenced to pay alimony divorce waiting period just prior pledge.

3.2 Judicial review Article 41 letter c Marriage law by deleting the word "can" and adding a definite witness for the husband who does not pay iddah alimony.

\section{References}

Abdul Manan. (2005). Penerapan Hukum Acara Perdata di Lingkungan Peradilan Agama, Jakarta: Penerbit Kencana.

Ahmad Tirmidzi, dkk. (2013). Ringkasan Fikih Sunnah Sayyid Sabiq, Jakarta: Pustaka Al-Kautsar.

Ahmad Warson Munawwir. (1997). Al-Munawwir: Kamus Arab-Indonesia, (Yogyakarta: Pustaka Progressif.

Ali/Inu, "Mantan Suami Kerap Abaikan Pemenuhan Hak Nafkah Pasca Cerai, ” in http://www.hukumonline.com, accessed on November $3^{\text {rd }} 2020$.

Ali Syariati. (1996). Humanisme, Antara Islam dan Mazhab Barat, Bandung: Pustaka Hidayah.

Amir Syarifuddin. (2006). Hukum Perkawinan Islam di Indonesia, Jakarta: Kencana Prenada Media.

Ester van Eijk, Sharia incorporated, Sharia and National Law in Saudi Arabia, Leiden: Leiden University.

Imam al-Hakim, al-Mustadrak 'ala al-Shahihain, Kitab al-Ahkam, Hadis No. 7165, $2^{\text {nd }}$ published. Kairo.

Imam Malik Ibn Anas. (1990). Al-Muwatta', Translator: Dwi Surya Atmaja, Jakarta: PT. Raja Grafindo Persada.

Kusnoto, Masa Pembayaran Mutah Dan Nafkah Iddan Kaitannya Dengan Hak Pengucapan Ikrar Talak (kajian Purusan Perkara Cerai Talak Yang Memuat Beban Mut'ah Dan Nafkah Iddah), badilag.net, accessed on November $2^{\text {nd }} 2020$.

Machmudin, Dudu Duswara. (2003). Pengantar Ilmu Hukum; Sebuah Sketsa, Bandung: PT Refika Aditama.

Marjanne Termorshuizen, (1999). Kamus Hukum Belanda, Jakarta: Djambatan.

Slamet Abidin dan Aminuddin, (1999). Fiqih Munkahat, Bandung: CV Pustaka Setia.

Syaikh Faishol bin Abdul Aziz Ali Mubarok, (1984). Nailul Authar, Penerjemah. A. Qadir Hasan et al, Surabaya: PT. Bina Ilmu.

Syaikh Kamil Muhammad Uwaidah, (1998). Fiqih Wanita, penerjemah M. Abdul Ghoffar, Jakarta: Pustaka Kautsar.

Sulaiman Rasjid, (2012). Fiqh Islam, Bandung: Penerbit Sinar Baru Algensindo Bandung Anggota IKAPI.

Tjitrosoedibio, (1979). Kamus Hukum, Jakarta: Pradnya Paramita, $4^{\text {th }}$ published.

Zainuddin Ali, (2006). Hukum Perdata Islam di Indonesia, Jakarta: Sinar Grafika.

Hermin Sriwulan was born in Malang, October 4th, 1981, completed the undergraduate degree from Islamic Religious Faculty majoring Sharia an Law, University of Muhammadiyah Malang in 2005, graduated master degree of Islamic Law from Graduate Program at the University of Muhammadiyah Malang, and Student of Law Science doctoral program at Brawijaya University of Malang. She currently working as Religious Court Judge at Magelang and now as Deputy Head of Religious Court at Magelang. 